\title{
The reasons women choose and stay in a geology major: a qualitative multi-case analysis
}

Ron E. Gray ${ }^{1 *} \mathbb{0}$, Alexis T. Riche ${ }^{2}$, Isabel J. Shinnick-Gordon ${ }^{1}$ and James C. Sample ${ }^{2}$

\begin{abstract}
Despite earning half of all science and engineering undergraduate degrees between 2007 and 2016 in the USA, women were awarded only $39 \%$ of earth science degrees in the same time period. In order to better understand why women are both choosing and staying in geology programs, we conducted a multi-case study of nine current female undergraduate geology majors at a large public university in the USA within a department that is at gender parity among its undergraduate majors. The main data source was audio-recorded critical incident interviews of each participant. Data from the interviews were analyzed through an iterative coding process using codes adapted from previous studies that focused on factors both internal and external to the department. The students said that personal interests, influence by others outside of the department, and introductory classes attracted them to the geology program, but once declared, departmental factors such as relationship with faculty caused them to stay. We also found an emphasis on female role models, especially those teaching introductory courses. We believe this study offers important insights into the ways in which factors leading to recruitment and retention play out in the lived experiences of female geology majors.
\end{abstract}

Keywords: Gender, Lived experience, Interview, Recruitment, Retention

From 2007 to 2016, women have earned about half of all science and engineering undergraduate degrees awarded in the USA (National Science Foundation, 2019). However, women are still underrepresented in geosciences as compared to other STEM fields (National Science Foundation, 2019). Women earn about $60 \%$ of biological science undergraduate degrees, but only $39 \%$ of earth science degrees (National Science Foundation, 2019). This is despite the fact that the number of earth science degrees awarded from 2007 to 2016 nearly doubled, while the total number of STEM degrees awarded increased by $40 \%$.

*Correspondence: ron.gray@nau.edu

1 Department of STEM Education, Northern Arizona University, P.O. Box 5697, Flagstaff, AZ 86011 , USA

Full list of author information is available at the end of the article
This study aims to investigate the factors that draw female students into geology majors (recruitment) within a department that is at gender parity among its undergraduate majors, as well as what factors make them stay (retention). Most previous studies have focused on why students are drawn to the study of geosciences at the undergraduate level (e.g., Levine et al., 2007; Pugh et al.; 2019; Sexton et al., 2018; LaDue \& Pacheco, 2013; Stokes et al., 2015). Some studies (e.g., Pugh et al., 2019; Sexton et al., 2018) have focused specifically on female students. However, little has been done to show why female students choose to remain in the geosciences through conferral of a degree. Many of these studies have been large in scale and essential in identifying important factors in recruitment and retention that we draw upon here. We chose to focus on a more individual level, examining the rich data of a small number of female student voices to 
provide a fuller picture of how these identified factors affect students' lived experiences. This study analyzes critical incident interviews from nine female students to identify the factors that not only influenced them to enter into a geology major, but also made them choose to remain in the major. We see the findings of our study as adding to not only the recruitment and retention literature, but we see them as relevant to departments' ongoing efforts toward recruiting and retaining women in the geosciences.

\section{Background}

To ground this study, we begin by examining relevant literature around recruitment and retention of geoscience majors. We then move to examining the literature for the recruitment and retention of women in STEM more generally and then the geosciences in particular. We highlight specific factors identified by previous studies that are used to inform our analysis of female geoscience student voices. Finally, we describe the theoretical framework and research questions guiding the study.

\section{Geoscience majors}

Hoisch and Bowie (2010) surveyed undergraduates in introductory geology courses and found that students perceived geology to be the least difficult of the sciences, and geology occupations to be low paying and low in prestige relative to the other sciences. They saw these negative perceptions as "a problem for recruitment" (p. 166). In a similar study, Sherman-Morris and McNeal (2016) showed that geosciences scored lower than other science subjects with respect to student perceptions in its ability to help the environment, help society, help them find a job, and provide a competitive salary.

In 2007, Levine et al. laid out a framework for a geoscience pipeline. Subsequent studies have added to their original framework, investigating the ways certain students fit in or fall out of the pipeline (Baber et al., 2010; LaDue \& Pacheco, 2013; Stokes et al., 2015). For example, half of those interviewed by LaDue and Pacheco (2013) said that taking an introductory geoscience class during their undergraduate studies led them to pick geoscience as a major. Engaging geoscience courses, especially those focusing on place-based geology and relevant community issues, can be particularly impactful in choosing geoscience as a major (Levine et al., 2007). Positive personal connections to family and teachers will also contribute to students picking a geoscience major, including parents encouraging the study of geology or even taking their children rock hunting during their childhoods (LaDue \& Pacheco, 2013). Positive academic mentors can both support and encourage the pursuit of geosciences and provide a connection to the professional social sphere of the field (Levine et al., 2007). Support from mentors can also improve students' feelings of their own self-efficacy (Hernandez et al., 2020; Levine et al., 2007).

\section{Women in STEM}

$\mathrm{Su}$ and Rounds (2015) found that women are drawn to STEM fields perceived to have opportunities to work with and help people, consistent with the overrepresentation of women in biology and psychology (National Science Foundation, 2019) and underrepresentation of women in more traditionally masculine fields such as computer science and engineering (Shapiro \& Sax, 2011). This has a recursive effect, as female STEM majors in these fields may not find enough female role models as faculty or graduate students, deterring retention of women in STEM fields (Shapiro \& Sax, 2011). Herrmann and colleagues (2016) note that it is important for women to have female role models in STEM fields to increase their self-efficacy. In a cross-disciplinary study of both chemistry and psychology students, Herrmann et al. (2016) found that female role models can help normalize feelings of not belonging or poor performance in early "weed out" STEM classes for female students, resulting in increased grades and lower dropout rates.

\section{Women in geosciences}

Other scholars have focused their research on understanding factors related to women in the geosciences, the focus of this study. For example, Cheryan et al. (2017) attribute the underrepresentation of women in maledominated STEM fields (which includes geosciences) to the combination of less early exposure to the field, a gender gap in self-efficacy, and a masculine culture in some STEM fields (including stereotypes about women and men in these fields and lack of female role models). Other recent studies have shown that female geoscientists are more than twice as likely to experience negative gender bias in their professions compared to males (Marín-Spiotta et al., 2020; Popp et al., 2019).

In terms of undergraduates, Sexton et al. (2018) investigated the differences between why men and women may choose a geoscience major. They found that women were more likely than men to say that they joined the major because they liked something about the department, which is supported by findings of Su and Rounds (2015). The examples Sexton et al. (2018) provide of student answers about "liking the department" all related to students liking the community or family feel of the department. Both male and female students mentioned this, but in their study, it was the second-most mentioned factor for women and second-least mentioned for men. Students at schools with a larger percentage of female geology graduates also more often cited "liking 
the department" as an important factor than students at schools with fewer female geology students.

Stokes et al. (2015) found differences between genders in critical incidents while in college leading to choice of geoscience major. In particular, they found that nearly twice as many men talked about career opportunities than women as an influence, and women were more likely than men to talk about negative experiences in required non-geoscience coursework. Thus, for women in the study, "employability and salary, which are often emphasized in geoscience recruiting, were not the most important factors in the decision-making process" (p. 260).

Examining the impact of the departments, Pugh et al. (2019) investigated why some departments are more successful at recruiting and retaining female students than others. They found that students at more successful departments reported greater institutional supports, greater perceived connection to instructors, and lower institutional barriers than those at less successful departments. Interestingly, they concluded that the success of departments effective at recruiting female students in their study was associated with supporting all students, not targeting interventions for female students alone.

\section{Theoretical framework and research questions}

Social cognitive career theory (SCCT; Lent et al., 1994, 2000) provided our theoretical framework for this study. Based on Bandura's general social cognitive theory (1986), SCCT focuses on the interplay among a variety of personal and contextual variables that are hypothesized to influence the processes through which people (a) develop basic academic and career interests, (b) make and revise their educational and vocational plans, and (c) achieve performances of varying quality in their academic and career pursuits. These variables include selfefficacy, outcome expectations, and goals. This theory has recently been utilized to understand women's selection of and persistence in STEM disciplines, including the geosciences (e.g., Jones et al., 2010; Lent et al., 2013; Miller et al., 2015; Sexton et al., 2018). In particular, Sexton et al. (2018) derived their coding categories, which we adapt here, from SCCT. These categories included the personal variables of 'interest in geology' and 'like outdoors' and the contextual variables of 'career opportunities', 'like the department', and 'encouraged by someone', as well as an 'other' category.

In this study we drew upon the relevant factors identified above, organized within a SCCT framework, to examine at a more individual level the factors that led women to choose and stay in geology majors within a department that is at gender parity among its undergraduate majors. We believe this study adds to the extant literature on the subject by providing rich, deep insight into this important yet highly complex issue. Specifically, we asked:

1. What factors led to current female geology majors choosing a geology major?

2. What factors led to current female geology majors staying in a geology major?

\section{Research design}

Most of the research involving recruitment and retention of female students in geoscience education has employed quantitative techniques (e.g., Hoisch \& Bowie, 2010; Pugh et al.; 2019; Sherman-Morris \& McNeal, 2016). Studies involving qualitative research methods are necessary in order to further explore factors identified in quantitative studies. Museus et al. (2011), in their research on the related literature regarding those factors that contribute to minority STEM success, described "the importance of moving beyond simplistic aggregated analyses to more complex understandings of the experiences and outcomes for various ethnic groups" (p. 20). Thus, the purpose of this research is not to generate findings that can be generalized across a population, but to provide rich, deep insight into an important issue within the specific context of a geoscience department at gender parity among its undergraduate majors. Thus, large numbers of participants were not essential for our purpose; a single person self-reporting an event determines both the criticality of the event and its impact.

We employed a qualitative multi-case study design (Creswell, 2007; Merriam, 1998; Stake, 2006) that investigated more than one case of students' decisions to enter and remain in a geology major. Each case was constructed based on the lived experiences of an individual student. These cases were investigated to create deep understandings about their decisions regarding their major through descriptive case study. A comparison of these cases explores common themes that transcend each individual case and provides the benefit of an "understanding of the aggregate" (Stake, 2006, p. 39).

\section{Methods}

This exploratory study is part of a larger project intended to positively impact the recruitment of students into geoscience majors (see Sample et al., 2019) and (Riche et al., 2019). In this study, we report on a qualitative multi-case study of nine female geology majors to examine in detail 
the factors that led them to choose and stay in geoscience majors.

\section{Researchers' positionality}

The authors share an interest in better understanding the factors that shape female students' decision to choose and stay in a geology major. Two of the authors of this study were situated within the geoscience department, one a male faculty member and another a female graduate student. Both, however, had limited connections with the undergraduate student participants. The other two authors, a male faculty member and female graduate student, were situated outside of the department and had no prior connections with the participants. Interviews were conducted by the female science education graduate student. The research team's positionality was along a continuum of insider and outsider, genders, and positions of power within the university system. Our diversity are lenses through which we may have interpreted data. We believe, however, that our diversity enriched the conduct of the study.

\section{Setting}

This study is situated within an undergraduate geology program at a large public university in the southwestern USA. The undergraduate program in geology offers emphases in applied geology, geophysics, and paleontology and heavily incorporates fieldwork and laboratory experiences into the degree. Despite the fact that the national average of female students graduating with degrees in geoscience was $40 \%$ as of 2018 (National Science Foundation, 2019), female undergraduates made up $52 \%$ of all geology majors at this university at the time of the study. For our purposes, we believe this reveals a program that is at gender parity within its undergraduate student population.

At the university, the geology faculty is part of a larger school that includes faculty in environmental science, sustainability, and climate science. Here, we focus on those faculty whose research and teaching aligns with the geology major. This group consists of eighteen full-time faculty. Of these, seven are female and eleven are male. While those at the rank of full professor are weighted toward male faculty ( 8 male, 2 female), the others on the tenure track are evenly split between male and female faculty. Lecturers, on the other hand, are majority female ( 3 female, 1 male). At this university, it is largely the lecturers who teach introductory courses for non-majors that are often an entry point into the geology major (LaDue \& Pacheco, 2013). Therefore, the majority of students do not enter the university as a declared geology major, but instead choose to declare their geology major in their freshmen or sophomore years. As in most US universities, the process of choosing and changing majors is an easy process.

\section{Participants}

We used convenience and snowball sampling (Miles \& Huberman, 1994) to recruit female undergraduate geology majors as participants in the study. We recruited participants through targeted emails, visits to geology courses, and recommendations from other participants. There were no criteria other than gender employed in our accepting participants. As the lived experience of all female geoscience majors were relevant to our analysis, it was not necessary to recruit a random sample. Nine female geology majors responded and participated in critical incident interviews as described below (see Table 1). All names are pseudonyms. Beyond gender, age, and year in major, no other demographic details were collected from participants.

\section{Data collection and analysis}

The main data source for this study was audio-recorded critical incident interviews of each participant. The critical incident technique has been used in several recent studies investigating educational and career choices (e.g., Levine et al., 2007; Stokes et al., 2015). Critical incidents are important events, in this case events that led students to choose and stay in a geology major (Serrat, 2017). This method yields qualitative data that is based on actual recalled experiences (Dunn and Hamilton, 1986). Each interview was conducted by the third author (female science education graduate student) with the same protocols and script as used by Stokes et al. (2015) and lasted approximately $30 \mathrm{~min}$. The full interview protocol can be found in the supplemental materials. The students were encouraged to recall as many types of experiences as possible regarding their choosing and staying in the geology

Table 1 Demographic data of participants

\begin{tabular}{lll}
\hline Participant & Year in major & Age \\
\hline Bethany & Junior & 21 \\
Celeste & Junior & 21 \\
Cynthia & Junior & 21 \\
Samantha & Sophomore & 20 \\
Emma & Junior & 21 \\
Elisabeth & Junior & 21 \\
Erin & Junior & 22 \\
Jamie & Senior & 22 \\
Janice & Senior & 27 \\
\hline
\end{tabular}


major. Follow-up questions focused on how they felt during the experiences, or critical incidents.

We were particularly interested in looking more closely at what about the women in the geology program drew them into the field and helped keep them there. Thus, we adapted Sexton et al's (2018) categories, derived from SCCT, from investigating gender differences in what drew undergraduate students into the major (see Fig. 1). This allowed us to connect our results to the previous literature. The Sexton et al. (2018) categories of 'interest in geology' and 'likes the outdoors' were combined into a larger 'personal interest' category. In addition, the catchall 'other' category was found to include statements concerning 'personal values' and 'course experiences' which added as coding categories. Two researchers independently coded the interviews and consolidated the codes between the two documents to come up with a comprehensive and reliable set of coded data. See Table 2 for descriptions and example coded incidents for each coding category.

In addition to the codes above, each incident was categorized as negative or positive, as we found cases where each of these categories was either a positive or negative influence. For instance, students say that the "Geologic Disasters" course, an introductory class for non-majors, was a large part of getting them interested in the geology major; this would be a positive influence. Unsupportive families of students who joined the geology major would fall under negative influence. We also grouped incidents on whether it was an incident that got someone "into" the

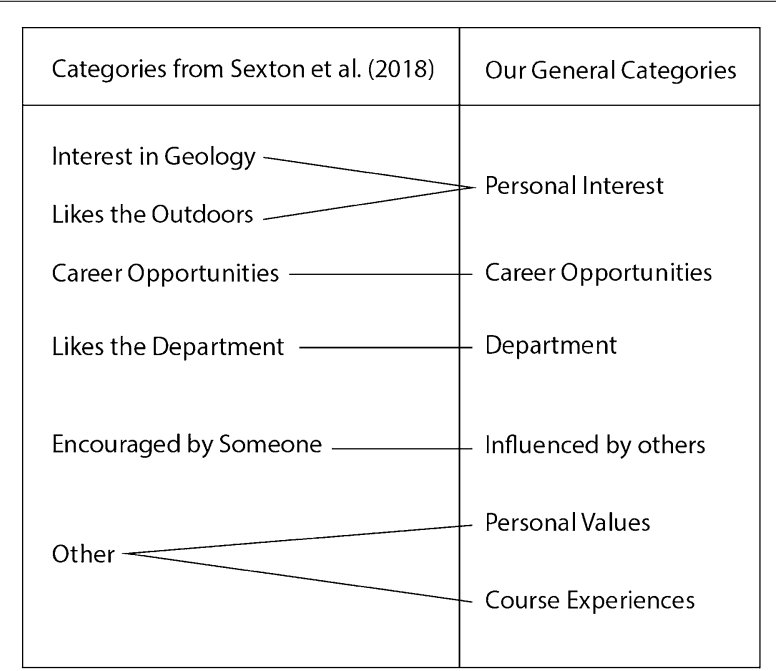

Fig. 1 Coding scheme, as compared to Sexton et al. (2018). The data from critical incident interviews were analyzed through an iterative coding process using codes adapted from previous studies that focused on factors both internal and external to the geoscience department program (recruitment) or helped them "stay" in the program (retention). Previous studies look largely at factors that influence recruitment, so drawing out the differences between recruitment and retention factors allowed us to look at what factors affect both recruitment and retention. Two authors coded all data and reached an $84 \%$ inter-rater reliability. All disagreements were resolved to reach $100 \%$ inter-rater reliability.

\section{Trustworthiness}

Lincoln and Guba (2000) discuss trustworthiness as dependent on credibility, transferability, dependability and confirmability. Every effort was made to assess the data for credibility and confirmability; however, Rossman and Rallis (2003) maintained that in qualitative studies, the data must be approached with humility and must be useful in answering the research questions while understanding that the data is in the perspective of the participant, not based on the researcher's notions. In terms of credibility and dependability, we shared our diverse individual perspectives and positionalities as a research team that we believe enriched the conduct of the study. With this diversity in mind, we took care to increase the trustworthiness of our findings through an extensive process of inter-rater reliability. Due to the qualitative and context-specific nature of this study, we do not imply generalization across the population of undergraduate female geoscience students. We strove to provide sufficient detail of the context here for others to determine the relevancy to their own contexts.

\section{Findings and discussion}

The findings highlighted here provide insights into the factors that led our group of nine women to choose and stay in the geology major in the context of a geoscience department that was at gender parity among its students. By describing and understanding the critical incidents that led to each individual making the decision to choose and stay in the major, we have uncovered a number of useful patterns that relate to previous large-scale studies of the recruitment and retention of women in the geosciences as well as the SCCT framework. Below we describe a number of relevant patterns.

We begin by providing a general overview of the coded incidents. Table 3 shows the categories within which each student mentioned at least one critical incident. Note that the Course Experience category has no mentions in retention. This is by design, as the category only includes out-of-major (high school or introductory-level college) classes. When students decide to join the geology major, their classes are in the department and therefore fall under the Department category. 
Table 2 Definitions and example instances of each code Adapted from Sexton et al. (2018)

\begin{tabular}{|c|c|c|}
\hline Category & Definition & Example \\
\hline Personal interest & $\begin{array}{l}\text { Includes factors related to interests such as the discipline of } \\
\text { geology, travel, and the outdoors }\end{array}$ & $\begin{array}{l}\text { "Another thing is, I've always been interested in history. I've } \\
\text { taken history classes, and they're full of a lot. I like that geol- } \\
\text { ogy is like the history of the Earth, so I think that's super cool." } \\
\text { (Bethany) }\end{array}$ \\
\hline Career opportunities & $\begin{array}{l}\text { Includes factors related to the career opportunities associated } \\
\text { with the discipline }\end{array}$ & $\begin{array}{l}\text { "And geology just seemed the most applicable. And it also } \\
\text { seems like if worse came to worse and I needed to get an } \\
\text { entry level job that was not terribly paying, that would also } \\
\text { be a fallback. It felt like the safest option as a fall back plan } \\
\text { too." (Janice) }\end{array}$ \\
\hline Department & $\begin{array}{l}\text { Includes factors related to aspects of the geology depart- } \\
\text { ment, geology classes and field experiences, and/or geology } \\
\text { faculty }\end{array}$ & $\begin{array}{l}\text { "The professors really. You know it is } 240 \text { is known to be the } \\
\text { make-or-break for geology majors. The professor, [professor } \\
\text { name], just really showed us what geology is. It's experiential } \\
\text { learning, learning by experience instead of just lecturing, } \\
\text { which I really, really liked. It's really nice to not be in a class } \\
\text { where you can learn on your own. I feel like it helps you learn } \\
\text { better. I took a microbiology class. I was in a lecture with } 180 \\
\text { people. It was awful. The professors didn't know you but the } \\
\text { geology program they all know you. They build a relationship } \\
\text { with you. That really kind of pushed me towards geology } \\
\text { instead of biomed." (Samantha) }\end{array}$ \\
\hline Influenced by others & $\begin{array}{l}\text { Includes factors related to encouragement by family, friends, } \\
\text { teachers, and/or non-major professors }\end{array}$ & $\begin{array}{l}\text { "One of my really good friend's dad, he actually went to [univer- } \\
\text { sity name] and did his master's here as well. And then he has } \\
\text { this water company and they dig wells. And the whole time, } \\
\text { my whole life I've always been like, 'No one really knew what } \\
\text { Marvin did.'It's not like none of us kids, we were like,'What is } \\
\text { geology? There is a well.' And even his son would be like, 'He } \\
\text { digs wells.'You can't have a career doing that. Right?' So he } \\
\text { was a pretty big influence and he was always so knowledge- } \\
\text { able too." (Elisabeth) }\end{array}$ \\
\hline Personal values & $\begin{array}{l}\text { Includes factors related to values such as helping others, the } \\
\text { environment, and persistence }\end{array}$ & $\begin{array}{l}\text { "I really appreciate that what you do matters and I always try } \\
\text { to tie it into something, well like this is an issue that needs } \\
\text { fixing, and you are the only people that understand the issue, } \\
\text { so you need to come up with this solution for it. I guess there } \\
\text { is a lot of responsibility that comes with that too and it's } \\
\text { on a level I didn't expect to have so early. I really appreciate } \\
\text { not only am I doing something that I like I am doing it with } \\
\text { people that I trust and we are trying to work on things that } \\
\text { should benefit more people. Even if we can't explain to them } \\
\text { that what we are doing is important, they will still benefit." } \\
\text { (Celeste) }\end{array}$ \\
\hline Course experiences & $\begin{array}{l}\text { Includes factors related to course experience that occurred } \\
\text { before a student declared as a geology major }\end{array}$ & $\begin{array}{l}\text { "My high school year I took a geology course. I always wanted } \\
\text { to be a doctor at first. I came in with biomed and then before } \\
\text { I actually started at [university name], which I did a dual } \\
\text { major of biomed and geology. I was still taking both of those } \\
\text { classes kind of getting a feel what I wanted to take. In high } \\
\text { school I took a geology class and I fell in love with it. I was } \\
\text { like, I really like this. I want to explore this more." (Samantha) }\end{array}$ \\
\hline
\end{tabular}

Across nine interviews, 154 critical incidents were identified and coded into the six categories seen in Fig. 1. Each incident was then coded as having a positive or negative influence on the interviewee. In terms of recruitment, Personal Interest, Influenced by Others, and Course Experience were dominant (positive) factors, mentioned by seven of the nine students. The Department followed with six students citing it as an important positive influence. In terms of retention, the dominant factor was the Department. All nine students cited the department as influential in their decision to stay in the major, the only category mentioned by all students. Overall, more students made positive mentions than negative in every category except in Personal Values recruitment.

Interestingly, there are no mentions of Career Prospects deterring students in the recruitment stage, which is cited as a major reason for why students choose not to study geoscience (Hoisch \& Bowie, 2010). Once in the major, students are still not disheartened at their future prospects, as there were no negative retention mentions of Career Prospects. Similarly, no students mentioned any 


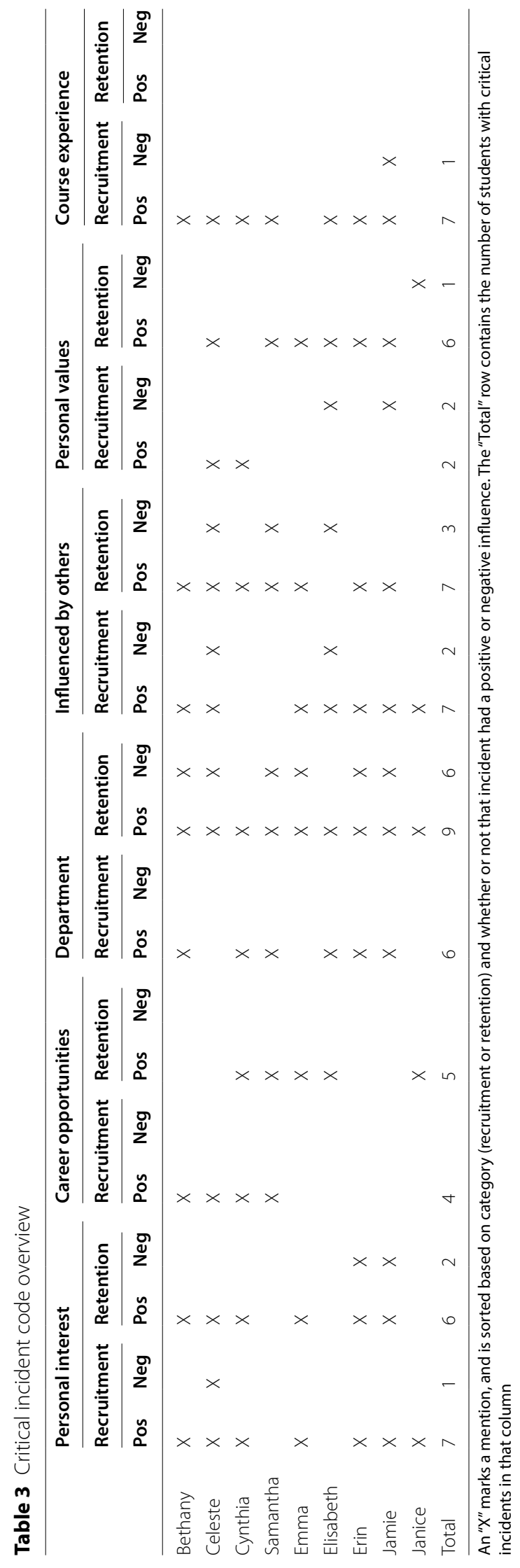


aspect of the department deterring them from joining the major.

\section{Recruitment}

Our first research question was about recruitment of female geology majors. Specifically, we asked: What factors led to current female geology majors choosing a geology major? This section is organized by the coding categories.

\section{Personal interest}

For seven students, their pre-existing interests in the outdoors and history influenced their major selection (often after they discovered geology in college and realized that the geology major matched well with those interests). Bethany says that she did not have much prior knowledge of geology before university, but she did like history and felt that geology fed that interest. As she states, "I've always been interested in history. I've taken history classes. I like that geology is like the history of the Earth." An interest in nature and the Earth is a more obvious connection to geology, which was specifically noted by Janice. She also describes not knowing much about geology before deciding on a major, but after stumbling across it felt it fit perfectly with her other interests: "I didn't ever take geology in high school. I really had no idea what it was. But I just felt it was, after learning about it, I felt like it was a good framework to understand the natural world." Celeste, for example, connected with the storytelling aspect of the field: "It's very much like storytelling, but backwards. Some people can find it kind of boring and dry and I really enjoyed that storytelling aspect of it."

\section{Career opportunities}

Four students cited potential Career Opportunities as influential in their decision to enter the geology major. Much of the pre-existing knowledge of careers in geology for many students, like Bethany, revolved around being outside and not stuck at a desk job. She "didn't want to sit at a desk" and prefers "to go out in the field." The prospect of a profession with many opportunities to travel in addition to being outdoors also featured strongly in her selection of geology as a major. As Emma explains, "being in geology is one of the easiest ways to just be able to get out and see so much more than you think...I'm definitely excited to get out of school and get to that point where it's like I can go fly to China and see of the geologic structures there."

\section{Department}

Faculty influenced student major selection both through direct interactions and their enthusiasm in classes. All six students who cited the department for inspiring them to choose geology mention the enthusiasm of their instructors when talking about taking introductory-level courses. Cynthia, for example, says that they "just have so much enthusiasm for it and that got me excited." Others say that more direct interactions led to their major selection. For Elisabeth, a representative coming to her class to recruit students for another learning opportunity in geology influenced her. Someone "came into class and was like, 'Everyone sign up for our little field class.' And in class I did it... I was really excited about it. And that was probably what turned the tables for me the most actually." Erin says that she was already considering switching to geology from an environmental science major, but meeting with a faculty member is what really helped her finalize her decision. "That professor that I met with," she recalls, "was the one that pretty much influenced me to change my major. I think when I went to his office to talk to him I was already pretty set on changing my major, but I just remember I told him I want to work in something to do with climate change, and he pretty much guided me." Students mentioned female faculty members specifically 14 times, all in a positive way. Contrastingly, male faculty members were mentioned 10 times, two of which were negative. Faculty as a group were mentioned another 13 times.

The peer community of geology was not a major factor initially drawing students into the major. Celeste talks about the skepticism she had when she was initially told that geology would be a very communal and collaborative program. She says that "in the first few classes, they tell you that this is a communal thing, you can't do this alone. And you realize that's true, but you don't realize it's true until a year later." Janice knew a high school friend who had majored in geology, so the tight knit community is something she knew of beforehand, but she describes it as "intriguing" and not necessarily determining her major selection. She explains, "I think that another really unique component is that you, which is something that I did notice from [my friend] jumping back is that she had this really tight knit group of colleagues in her program that because they were spending all this camping time. It just intrigued me."

\section{Influenced by others}

Support from friends and family were mixed for this group of interviewees. Three of the students had a difficult time getting support from their parents and friends when they were considering declaring a geology major. They felt that their parents did not understand what the geology major was and that they themselves did not have enough knowledge to explain it. Celeste recalls, "When I switched my major that sophomore year I knew I was 
interested in Geology and I was taking these classes but I hadn't declared yet and I remember my family asking me, what are you going to do with a Geology degree and I couldn't tell them because I didn't really know." Three students felt that responses from friends and family were mixed, and three felt that their friends and family were supportive from the start. Bethany talked about how her grandmother was really excited that she was studying science: "My grandma, especially. She just moved in with us. My older brother was an accounting major, and she was like, 'Good for him, that's super exciting. But I'm so glad you're a science major!"'.

\section{Personal values}

Some students were driven to study geology because of its ties to the environment. Cynthia was raised by parents who instilled in her a responsibility to the planet. She felt that studying the natural world was important to its preservation. She explains, “...growing up it was always a very big, important deal to take care of the planet. Be good to nature, things like that. And so when I started learning about the Earth and its processes. I was just like 'wow, this is really cool'...kinda something that I grew up learning one side of it and now understanding how it actually works." Erin also had a pre-existing interest in the environment: "I just have always been really passionate about protecting national parks and that kind of stuff... I've always enjoyed being outside." She had always been guided by this interest and switched majors from environmental policy to geology in order to get more handson with the science.

Self-efficacy was also important and often a deterrent to incoming majors. For example, Jamie recalls thinking to herself, "I'm not a math person. I'm not a science person," so when she saw requirements for chemistry, physics, and calculus coursework, she thought, "No way I can do that." Overcoming this was a major milestone for her, and relationships with geology faculty, particularly her female introductory course instructor, played a large role in her ability to do so. Elisabeth had a similar experience, and after high school believed she was "terrible at math and science."

\section{Course experience}

Three students encountered geoscience in their coursework before coming to college. Elisabeth took a geoscience class in high school because she wanted to take an easier science, and was surprised to be interested in it. As she explains, "I was like 'ooh, geoscience,' for no reason at all other than I didn't want to take an advanced placement class. And it was like the best decision ever." Erin did not take a geoscience course, but chose to study polar ice caps for a required independent research project at the end of high school that captured her interest and started her on the path that led her to the geology major.

Five students were inspired to join the geology major after taking an introductory geology class for non-geology majors called Geologic Disasters once they entered college. Bethany, Celeste, Cynthia, Elisabeth, and Jamie all said they switched majors after taking this class. Jamie, for example, says that she "took Geologic Disasters [her] freshman year, [her] first semester... [she] did really, really well in the class, and [she] wasn't thinking at all about geology as a major." At the time she was a psychology major, but her Geologic Disasters experience and rapport with her female instructor put her on the path of geology. She attributes a lot of her choice to this instructor: "So actually, she says that I would have found it anyways into the major, but I don't know if I would have."

Cynthia was another student who entered the university with a non-STEM major that was influenced by this introductory course. She explains that she was undecided, working on prerequisites coursework, and took Geologic Disasters for a lab science credit. We note that this is quite common as geology is the lab science of choice for students who need a lab science but are trying to avoid sciences that are traditionally thought of as more difficult. Explaining how this class was a turning point for her, Cynthia says, "I took a geology class, and I thought wow this is really cool. I really liked learning everything that I was learning in the intro course, and I wanted to do it."

\section{Recruitment summary}

In terms of what drew our group of female students into the geology major, they mostly discovered how their Personal Interests related to geology after matriculating, prior to which they had little to no experience with geology. A passion for the outdoors or environmental stewardship seems to play a role in motivating students to choose a career in geology in this study as well as others (e.g., Sexton et al., 2018). This is similar to Levine et al.s (2007) finding that engaging geoscience courses focused on place-based geology and relevant community issues can be particularly impactful on choosing geoscience majors. Exposure to geology is minimal for most students before attending college (Hoisch \& Bowie, 2010), so controlling whether these students have positive or negative initial interactions in geology was critical in terms of recruitment for our participants.

Many of these students also felt that geology offered non-traditional career options, which appealed to their sense of adventure. This impression was fostered by the faculty, who spoke of geology enabling them to travel. Stokes et al. (2015) found that female majors were less likely to highlight career opportunities than men as an 
influence in choosing a geoscience major. While not entirely absent, career opportunities was at best a minor influence for our participants.

At this stage, professors' enthusiasm when teaching the class also encouraged students to look into joining geology, though one-on-one interactions became more important later. Pushing through self-efficacy issues was a major hurdle in female recruitment, but female instructors in these introductory classes were effective in quelling fears of inadequacy. Within the department, the lecturers that teach introductory classes for non-majors are majority female. Positive interactions with and enthusiasm from these female faculty members in addition to understanding and support strongly influenced female students to look into the geology major. This supports previous studies (e.g., Hernandez et al., 2020; LaDue \& Pacheco, 2013; Levine et al., 2007) that highlighted the importance of introductory geoscience courses and positive academic mentors in the recruitment of majors. Other influencers included friends, family members, and professional geologists encountered outside of the academic setting, and they had both positive and negative effects on recruitment. These included, as in LaDue and Pacheco (2013), parents encouraging the study of geology through rock hunting and other activities.

\section{Retention}

Our second research question was about retention of female geology majors. Specifically, we asked: What factors led to current female geology majors staying in a geology major? This section is organized by coding categories.

\section{Personal interest}

Several students said that they were not interested in or aware of geology as children. Janice, for example, stated: "I wasn't a kid who picked up rocks." Learning about geology is something she and other students grew to appreciate, as it helps to maintain and even grow their curiosity about the natural world and love of history/storytelling. Jamie, for example, explains that geology has opened her mind: "Because geology has given me the mind to wonder about any places that I go to, which I think is priceless. I think that's a really cool thing. Like never thought I'd like to think like that." Cynthia adds that geology makes life more interesting, saying, "You just get so excited about it when you can see things and know actually like this is how it happened."

Because the major is broad, however, some students like Erin struggled to maintain their interest in the topics that they found less engaging. Erin was originally an environmental science major. When she took an applied geology class, she enjoyed the "environmental policy and hydrology...but half the class [I] did not like at all," as it was focused on "construction and that kind of stuff, like engineering." Moments like this in the major made her question if this was really the right field for her.

\section{Career opportunities}

Five of the students interviewed discussed how, once in the major and thinking about the future, they felt that geology was a strong career move. Many of them did not know much about what they could do with a geology degree, but the breadth of classes and learning about professors' experiences and career paths reassured them of future prospects. Listening to professors talk about their journeys excited Cynthia about a future in geology: "They [geology faculty] would go and talk about all the different jobs they had had over the years and all the places they got to go. Just hearing that I could be outside and not at a desk, that's why I wanted to do anthropology originally...And that just got me really excited, listening to the teachers."

The versatility of a geology degree appealed to the students, something they did not know about before entering the major. Samantha, who originally entered her undergraduate studies as a biology major intending to become a doctor, realized that she wanted to study geology after taking an introductory course and learned about the applicability of a degree in geology through her course of study. For instance, she explains: "You could do geochemistry. You could do paleontology, which is like biology and geology. Geophysics. You could do geoengineering...There's really no end to what you can do with geology." Janice agrees that geology made long-term sense, saying, "...it gave me a really good, set of critical thinking skills that I've been able to apply."

\section{Department}

Once in the major, students noticed that many of the geology courses overlapped with each other. Skills learned seemed to translate to other areas of geology and to aspects of potential careers. Bethany, for example, says that she "really like[s] that the classes are so applicable." Students also liked that geology was "hands-on" and gave them a chance to learn outside on field trips and through undergraduate research. Many courses in the major are field-based or have several field experiences. Jamie was a student who says she started with feelings of low self-efficacy in the sciences. Finding she was "good at" the field components helped her in the major. 
The field trips, difficulty of the coursework, and course schedule (which backloads a lot of geology courses on the last 2 years of the program) were anxiety-inducing for five students, however, and often made these students question whether the geology degree was worth it. The senior capstone, for example, requires 2 weeks of field mapping, split into two trips throughout the semester. Samantha says, "It's really hard for me to give up a week of school and be able to keep my GPA up." The field focus, not the time away, is what Erin highlights, saying, "I'm pretty sure that a lot of people don't like that the major here is so field-based, which is awesome in its own way but I think all of us are stressed about it." To Bethany, the workload in general is overwhelming, and seeing her friends in less stressful majors with more free time makes her occasionally consider switching.

Once in the major, students liked the small size of the department and the amount of time they spent in the field, which they felt made it easier to access and interact with faculty. Several students also had an opportunity to do undergraduate research with faculty. For Bethany, getting to know the faculty and work with them on research projects are a highlight of the program: "You get so close with the professors in this field. Right now, I'm planning a trip with one of them for a research project. I've never had [a class with] her before, I've never met her before, and now, all of a sudden, we're going to Chile together."

Seven students appreciated that they could talk to their professors outside of class, and that faculty offered helpful guidance. Elisabeth felt that she could go to her professors to ask about the next steps in her STEM career after her undergraduate degree. She recalls, "I was like, 'How did you become a professor?' Because he's the coolest person. He's so funny. And he's really fun to talk to. He always makes us laugh. And he's a really good teacher and so I was like,

'How did you become a professor?' And he told me his life story about master's degrees and doctorate." Four of those students also feel personal connections with faculty members. Bethany talked about appreciating being able to talk to faculty about all kinds of questions. She says, "I think that's something that's super great is that I know I can go to her and ask her any question that I have, whether it be personal or educational, and she'll be there to respond to me. It's not a scary thing to go and talk to the professors here, I think, which is really great." Though relationships with all professors were important in female students' choice of major, female role models in the department were particularly important.

For three students, knowing a few other people in their major helped them get through the non-departmental prerequisites. The geology major requires students to take introductory chemistry, physics and math coursework. These courses were intimidating for some, but having a geology peer in the class was helpful. Celeste talked about finding a geology peer in her physics class: "We became like partners in that class because everyone else was a stranger." Jamie also mentions that having other geology peers helped her to have people to commiserate with about the difficulty of these courses, and also mentions that working collaboratively with her geology peers helped her get through them. All three of these students found that having someone else they knew from their major in these larger science lectures was helpful. It gave them someone to commiserate with and someone to work with.

Within the major classes in the department, six students found it helpful that class and cohort sizes were small, especially compared with other science majors at the university. In addition to the small community, it was the collaborative nature of each community of geology peers that was significant. Samantha, a double-major in geology and engineering, also found it significant that there were more women in her geology program, and that both men and women were supportive and non-discriminatory of each other. She elaborates, "Luckily, our geology here, there's a lot of women, which is not common but it's great. But I know what it feels like to be one of the only women in a very large class."

\section{Influenced by others}

Some students had positive support from friends and family throughout their participation in the geology major. This was especially true for the two students who were first-generation college students in their family. As Jamie notes: "So neither of my parents completed college degrees. So they are the most supportive people ever and they don't really like, I don't think they really know what I mean, I don't really know what all geology entails, you know, but they were kind of like, oh, I have a friend whose son did oil and gas."

Three students, however, still faced a lack of family support in their choice of major. Samantha, for example, explains, "My friends gave me so much slack. My family gave me slack." Elisabeth said that her family was initially "shocked" about her choice of major because they did not think she could do a science degree, but now that she is in the major her parents have gotten used to the idea, they occasionally asked questions like, "Well, if she can do science, why doesn't she become a doctor?"'.

\section{Personal values}

Three students discovered a passion for caring for people and the environment after entering the geology major, such as Celeste, who continues in the geology major because she feels a responsibility to become a person that 
really understands environmental issues, then "you need to come up with this solution for it."

Other values motivated students to stay in the major as well including persistence and self-efficacy. Because the geology major requires typically challenging classes like chemistry, physics, and upper level math, many students struggled. However, students like Jamie felt that this helped her grow. Jamie describes these feelings: "I have struggled in the courses and done well, which makes me feel like the struggle has brought me success." Jamie also felt driven to "finish where [I] started... [I] didn't want to quit when [I] was so close," which motivated her to keep pushing forward with the geology major despite the difficulties.

\section{Retention summary}

The most discussed factor in female retention was the Department, of which many different aspects of which were mentioned. Students said they felt the courses were concrete and applicable, as well as incorporated more hands-on learning than in other majors. However, this coursework tended to be demanding, intense, and backloaded, which made students feel like dropping out, especially because self-efficacy in STEM was not high for many of them. This was affected by the department in two ways: through building up camaraderie in a smaller cohort that supported each other and by encouraging more face-to-face interaction with faculty, who were better able to support these students because their relationships were stronger. Female professors, in particular, acted as both role models and confidantes for these female students. Other factors included a passion for geology and what careers they could pursue after their degrees, which most discovered after joining the major. It is worth noting that, unlike in previous studies (MarínSpiotta et al., 2020; Popp et al., 2019), our participants reported no incidents of gender bias during their time in the major.

According to a study by Su and Rounds (2015), women will seek out STEM fields with opportunities to work with and help people. This is consistent with what the women interviewed in this study felt. They frequently mentioned that the community in the geology department, including faculty and peers, was important for their continuance in the major. Levine et al. (2007) found that geology can also be more welcoming than other STEM fields such as engineering at a university level because it is more collaborative than competitive. Six of the nine women interviewed over the course of this study mentioned the importance of peer group interactions once they entered the major.

Female role models are important for the self-efficacy of female students (Herrmann et al. 2016). Some students sought female counsel for math and science courses outside of the major as well, which is consistent with findings that female students have less assurance in their math and science skills (Shapiro \& Sax, 2011; Stokes et al., 2015) as well as studies that suggest female role models specifically normalize those feelings so that female students can overcome them (Herrmann et al. 2016).

Shapiro and Sax (2011) suggested that faculty treatment of female students was even more important than the treatment of their peer group. Samantha is a double major in geology and civil engineering and sees a drastic difference in the way she is treated by faculty and peers in classes across majors. To her, geology is much more welcoming and lacks much of the sexism she is subjected to by both students and faculty in her engineering major classes. In regards to her civil engineering major, Samantha says, "It's intimidating. It sucks when professors will only call on men and never call on women, never ask women questions. When your fellow peers disregard what you say. I mean, it's definitely noticeable." However, she "never felt that with the geology program." In regards to her peer group, "The women are great. I mean, they're all supportive of each other. Same with the men. We all work together." She feels similarly about faculty treatment of women, saying, "The professors in that program do not care about your gender...They see you as equals and judge you by how hard you work. And that's something that I extremely appreciate."

\section{Limitations}

As with most multi-case studies, the generalizability of this study is limited by the small sample size of nine participants. However, as the majority of studies on female student recruitment and retention in this area are larger quantitative studies, we believe this "deep dive" into a smaller sample provides valuable information on how the factors identified by previous studies played out in our participants' lived experiences. We also acknowledge that one-time, reflective interviews may not fully capture the experience of our participants. Subsequent long-term, longitudinal studies would be more nuanced and better able to track changes in female students' attitudes toward their geology major over time.

\section{Implications}

Our findings provide implications for geology departments interested in attracting and retaining female majors. We highlight three here. First, intentional efforts to reach parity in terms of faculty gender is important for the recruitment and retention of female geology majors. While some departments have created targeted interventions to attract female students, our findings support the claim that the presence of female faculty members at 
different academic ranks provides the role models and mentors needed to attract and retain female students in the major. While there are certainly factors beyond the gender makeup of the faculty important in this context, a diverse faculty is necessary for to a diverse student body.

Second, many of the students in this study-firstgeneration college students, transfers from non-STEM majors, students for whom traditional science classes (e.g., physics or chemistry) were daunting-are the students that majored in geology. It should be a reminder to departments to not dissuade the non-major in the introductory class because they lack a science background. This study should remind faculty to recognize students who are excelling, to ask students who seem interested if they want to talk a bit more. For some, that was the turning point in their major selection. The cohort-driven major also seemed to benefit these students in their community building within the department. Students benefit from each other through friendship and mutual struggle through the required classes of the major in and out of the geology department. Undergraduate research was not mentioned by students as much as we expected even though many of these students were involved in some sort of undergraduate research or field schools where they spent a lot of time with their peers and faculty.

Finally, we highlight the importance of the introductory non-major courses in recruiting female geology majors. Unlike other STEM fields, incoming university students are significantly less likely to have meaningful experiences or backgrounds in the geosciences as was the experience for the majority of our participants. Therefore, the introductory courses, most often taken as part of liberal studies requirements, play an outsized role in making students aware of the major, the department, and potential career opportunities. We encourage departments to recognize the importance of these courses as well as the influence female instructors at this level made on our participants' choice to join the major.

\section{Conclusions}

In this study, we drew upon the relevant factors from the research literature to examine at a more individual level the factors that led women to choose and stay in geology majors within a department that is at gender parity among its students. We employed a qualitative multicase study design (Creswell, 2007; Merriam, 1998; Stake, 2006) to investigate nine individual cases of students' decisions to enter and remain in a geology major. Each case was constructed based on the lived experiences of an individual student. A comparison of these cases revealed common themes that transcend each individual case. We believe this study adds to the extant literature on the subject by providing rich insights into this important yet highly complex issue. Importantly, we believe our study provides rich context from which to better understand the ways in which previously identified factors of recruitment and retention play out in the lived experiences of female geology majors.

Personal interests and values, such as a passion for the outdoors and the environment, was an important factor for many of the participants choosing the major. The impact of others in their lives, including family and friends, was quite mixed with some lending support and others discouragement about the major and future prospects. Previous course experiences were important as well. While some had experiences in high school, most of our participants were introduced to the field through non-major introductory courses. These courses, taught largely by female faculty, played an outsized role in our participants' decisions to become geology majors. Once in the major, the departmental factors were the most influential on retaining them in the major. This included the influence of strong female faculty role models, faculty mentorship (often by female faculty members), and a strong overall sense of community often bolstered by field work and the perceived smaller size of the department.

It is worth reiterating that this study was in the context of a geology department at gender parity in terms of its undergraduate student population. In a recent study, Pugh et al. (2019) found that students at more successful departments in recruiting women reported greater institutional supports, greater perceived connection to instructors, and lower institutional barriers than those at less successful departments. While we did not compare cohorts of female geology majors across departments, these factors resonate well with the findings we report here. We agree with their conclusion that the success of departments effective at recruiting female students in their study was associated with supporting all students, not targeting interventions for female students alone. For our participants, the presence of a cohort of female faculty members across academic ranks allowed them to see themselves in the field and as part of the departmental community in ways that would not be as readily available in departments where female faculty members were the exception, not the rule.

\section{Acknowledgements \\ The authors sincerely thank the female undergraduate geology majors for their participation in this study.}

Authors' contributions

All authors shared in planning, conducting, analyzing the results, and writing the manuscript of this work. All authors read and approved of the final manuscript. 


\section{Funding}

Our research is supported by NSF under Grant No. ICER-1801768. Any opinions, findings, conclusions, or recommendations expressed are those of the authors and do not necessarily reflect the NSF's views.

\section{Availability of data and materials}

The datasets used during the current study are available upon request from the corresponding author.

\section{Declaration}

\section{Competing interests}

The authors declare that they have no competing interests.

\section{Author details}

${ }^{1}$ Department of STEM Education, Northern Arizona University, P.O. Box 5697, Flagstaff, AZ 86011, USA. ${ }^{2}$ School of Earth and Sustainability, Northern Arizona University, 624 S Knoles Dr., Flagstaff, AZ 86011, USA.

Received: 9 February 2021 Accepted: 6 May 2021

Published online: 17 May 2021

\section{References}

Baber, L. D., Pifer, M. J., Colbeck, C., \& Furman, T. (2010). Increasing diversity in the geosciences: Recruitment programs and student self-efficacy. Journal of Geoscience Education, 58(1), 32-42

Bandura, A. (1986). Social foundations of thought and action: A social cognitive theory. Prentice Hall.

Cheryan, S., Ziegler, S. A., Montoya, A. K., \& Jiang, L. (2017). Why are some STEM fields more gender balanced than others? Psychological Bulletin, 143(1), $1-35$

Creswell, J. W. (2007). Qualitative inquiry \& research design: Choosing among five approaches. (2nd ed.). Sage.

Dunn, W. R., \& Hamilton, D. D. (1986). The critical incident technique-A quick guide. Medical Teacher, 8(3), 207-215

Hernandez, P. R., Adams, A. S., Barnes, R. T., et al. (2020). Inspiration, inoculation, and introductions are all critical to successful mentorship for undergraduate women pursuing geoscience careers. Communications Earth \& Environment, 1, 7. https://doi.org/10.1038/s43247-020-0005-y

Herrmann, S. D., Adelman, R. M., Bodford, J. E., Graudejus, O., Okun, M. A., \& Kwan, V. S. (2016). The effects of a female role model on academic performance and persistence of women in STEM courses. Basic and Applied Social Psychology, 38(5), 258-268

Hoisch, T. D., \& Bowie, J. I. (2010). Assessing factors that influence the recruitment of majors from introductory geology classes at Northern Arizona University. Journal of Geoscience Education, 58, 166-176

Jones, B. D., Paretti, M. C., Hein, S. F., \& Knott, T. W. (2010). An analysis of motivation constructs with first-year engineering students: Relationships among expectancies, values, achievement, and career plans. Journal of Engineering Education, 99(4), 319-336

LaDue, N., \& Pacheco, H. A. (2013). Critical experiences for field geologists: Emergent themes in interest development. Journal of Geoscience Education, 61, 428-436

Lent, R. W., Brown, S. D., \& Hackett, G. (1994). Toward a unifying social cognitive theory of career and academic interest, choice, and performance. Journal of Vocational Behavior, 45(1), 79-122

Lent, R. W., Brown, S. D., \& Hackett, G. (2000). Contextual supports and barriers to career choice: A social cognitive analysis. Journal of Counseling Psychology, 47(1), 36

Lent, R. W., Miller, M. J., Smith, P. E., Watford, B. A., Lim, R. H., Hui, K., Ashley Morrison, M., Wilkins, G., \&Williams, K. (2013). Social cognitive predictors of adjustment to engineering majors across gender and race/ethnicity. Journal of Vocational Behavior, 83(1), 22-30
Levine, R., González, R. Cole, S., Fuhrman, M., \& Le Floch, K. C. (2007). The geoscience pipeline: A conceptual framework. Journal of Geoscience Education, 55(6), 458-468

Lincoln, Y. S., \& Guba, E. G. (2000). The only generalization is: There is no generalization. In R. Gomm, M. Hammersley, \& P. Foster (Eds.), Case study method. (pp. 27-44). Sage.

Marín-Spiotta, E., Barnes, R. T., Berhe, A. A., Hastings, M. G., Mattheis, A., Schneider, B., \&Williams, B. M. (2020). Hostile climates are barriers to diversifying the geosciences. Advances in Geosciences, 53, 117-127. https://doi.org/10 5194/adgeo-53-117-2020

Merriam, S. B. (1998). Qualitative research and case study applications in education. (2nd ed.). Jossey-Bass.

Miles, M. B., \& Huberman, A. M. (1994). Qualitative data analysis: An expanded sourcebook. Sage

Miller, M. J., Lent, R. W., Lim, R. H., Hui, K., Martin, H. M., Jezzi, M. M., Bryan, N. A. Morrison, M. A., Smith, P. E., Watford, B., Wilkins, G., \& Williams, K. (2015) Pursuing and adjusting to engineering majors. A qualitative analysis. Journal of Career Assessment, 23(1), 48-63

Museus, S. D., Palmer, R. T., Davis, R. J., \& Maramba, D. (2011). Racial and ethnic minority students' success in STEM education (special issue). ASHE Higher Education Report, 36(6), 1-140

National Science Foundation. (2019). Women, minorities, and persons with disabilities in science and engineering. Retrieved from https://ncses.nsf.gov/ pubs/nsf19304/digest.

Popp, A. L., Lutz, S. R., Khatami, S., Van Emmerik, T. H., \& Knoben, W. J. (2019). A global survey on the perceptions and impacts of gender inequality in the Earth and space sciences. Earth and Space Science, 6(8), 1460-1468

Pugh, K. J., Phillips, M. M., Sexton, J. M., Bergstrom, C. M., \& Riggs, E. M. (2019). A quantitative investigation of geoscience departmental factors associated with the recruitment and retention of female students. Journal of Geoscience Education, 67(3), 266-284

Riche, A., Shinnick-Gordon, I., Gray, R.E., \& Sample, J.C. (2019). Choosing and staying in a geoscience major: A qualitative multi-case analysis of current female majors. Paper presented at the annual meeting of the Geological Society of America. Phoenix, AZ

Rossman, G. B., \& Rallis, S. F. (2003). Learning in the field: An introduction to qualitative research. Sage.

Sample, J.C., Cruickshank, B.J., Gray, R.E., Reid, M., Riche, A., \& Shinnick-Gordon, I. (2019). Exploration of recruitment of earth scientists (EXPLORES) at Northern Arizona University through collaboration between geology and chemistry departments. Paper presented at the annual meeting of the American Geophysical Union. San Francisco, CA

Serrat, O. (2017). The critical incident technique. In Knowledge Solutions (pp. 1077-1083). Singapore: Springer.

Sexton, J., Pugh, K., Bergstrom, C., \& Riggs, E. M. (2018). Reasons undergraduate students majored in geology across six universities: The importance of gender and department. Journal of Geoscience Education., 66(4), 319-336

Shapiro, C. A., \& Sax, L. J. (2011). Major selection and persistence for women in STEM. New Directions for Institutional Research, 2011(152), 5-18

Sherman-Morris, K., \& McNeal, K. S. (2016). Understanding perceptions of the geosciences among minority and nonminority undergraduate students. Journal of Geoscience Education, 64, 147-156

Stake, R. E. (2006). Multiple case study analysis. Guilford Press.

Stokes, P., Levine, R., \& Flessa, K. (2015). Choosing the geoscience major: Important factors, race/ethnicity, and gender. Journal of Geoscience Education. 63(3), 250-263

Su, R., \& Rounds, J. (2015). All STEM fields are not created equal: People and things interests explain gender disparities across STEM fields. Frontiers in Psychology, 6, 189

\section{Publisher's note}

Springer Nature remains neutral with regard to jurisdictional claims in published maps and institutional affiliations. 